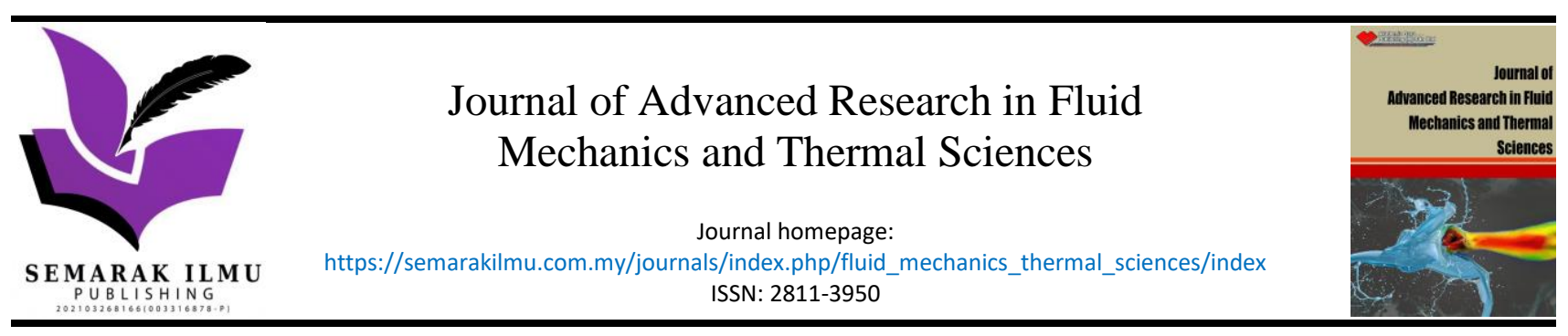

\title{
A Comparative Study of Wind Characteristics Between South-Western and South-Eastern Thailand Using Different Wind Turbine Models
}

\author{
Ismail Kamdar ${ }^{1}$, Juntakan Taweekun ${ }^{2, *}$ \\ Energy Technology Program, Faculty of Engineering, Prince of Songkla University, Hat Yai, 90110, Songkhla, Thailand \\ 2 Department of Mechanical and Mechatronics Engineering, Faculty of Engineering, Prince of Songkla University, Hat Yai, 90110, Songkhla, \\ Thailand
}

\section{ARTICLE INFO}

\section{Article history:}

Received 28 September 2021

Received in revised form 9 January 2022

Accepted 11 January 2022

Available online 5 February 2022

\section{ABSTRACT}

\begin{abstract}
Globally, wind energy has proven to be one of the most sustainable sources of energy. Wind energy assessment plays a critical role on determining installation of wind turbines worldwide. This work presents the technical evaluation of wind energy potential using three available wind turbine models for prospective onshore wind farm in the southern Thailand at Krabi and Songkhla sites. Ten-minute interval wind data over a period of 3 to 4 years obtained from Weather Observing Station is utilized to observe the diurnal and monthly wind speed, as well as frequency distribution. WAsP program is applied for energy yield calculations and wind resource maps. Our results reveal that Krabi and Songkhla has the highest mean wind speed of $4.39 \mathrm{~m} / \mathrm{s}$ in December and $3.91 \mathrm{~m} / \mathrm{s}$ in February, respectively. The prevailing wind direction in Krabi and Songkhla are north-east and south-east, respectively. WAsP analyses show that the total net AEP for Krabi is $7163.782 \mathrm{MWh}, 7762 \mathrm{MWh}$ and $12731 \mathrm{MWh}$ using $275 \mathrm{~kW}, 300 \mathrm{~kW}$ and $500 \mathrm{~kW}$ wind turbine models, respectively. Similarly, the total net AEP for Songkhla is $7116.63 \mathrm{MWh}$ $7775.245 \mathrm{MWh}$ and $12390 \mathrm{MWh}$ using $275 \mathrm{~kW}, 300 \mathrm{~kW}$ and $500 \mathrm{~kW}$ wind turbine models, respectively. The total capacity factor for Songkhla and Krabi is $29.1 \%$ and $28.3 \%$, respectively. Our results indicate that Enercon E-40/5.40 $500 \mathrm{~kW}$ wind turbine model produces the highest total gross AEP and total net AEP for Krabi and Songkhla sites. Besides, the Vergnet GEV MP-C 275 kW turbine model shows slightly higher capacity factor in case of both sites. The findings of this study reflect that small to medium size wind turbines can be utilized to generate electricity at the sites.
\end{abstract}

Wind energy potential; Wind characteristics; Wind turbine model; WAsP; Thailand

\section{Introduction}

In recent decades, the demand of energy has increased globally as a result of growing population and socio-economic progress. The overall energy consumption will rise up to 6\% globally during 20102040 as reported by the International Energy Outlook (IEO). Negative impacts of greenhouse gas (GHG) on environment and security of energy supplies have made the government organizations to increase the exploitation of various sources of renewables. Wind energy is one of the clean and

\footnotetext{
* Corresponding author.

E-mail address: juntakan.t@psu.ac.th

https://doi.org/10.37934/arfmts.92.1.149161
} 
inexhaustible sources of renewables and it can be utilized for the generation of electricity by means of wind turbines [1,2].

It is significant to evaluate the wind energy potential technically by knowing characteristics of wind in order to estimate the annual electricity production at potential locations [3]. It provides a pathway for wind energy practitioners with the necessary confidence to study their options to confront the increasing energy demands and mitigating risks [4,5]. To study these wind characteristics, various researchers have used different approaches such as Weibull, Rayleigh and Wind Atlas Analysis and Application Program (WAsP) [6].

Researchers in different countries scrutinized the wind energy potential at specific location using various scientific methods. For example, Adaramola et al., [7] used Weibull parameters to investigate wind energy potential in the coastal parts of Ghana. Solyali et al., [8] inspected wind resource assessment in Cyprus using the Weibull distribution and WAsP. They examined WAsP model more efficient compared to other methods. Wang et al., [9] performed an inclusive study regarding wind statistics along with wind power potential at four localities in China. Promsen et al., [10] and Nouri et al., [11] identified optimal sites for wind turbine installation by using short term wind statistics and WAsP model. Boudia and Guerri [12] used long term wind statistics along with WAsP model to study wind energy potential. Mohammadi et al., [13] used different approaches to measure the Weibull parameters and analyse daily power density in the south part of Alberta, Canada. Sharma and Ahmed [14] studied wind resource assessment using WAsP in the southern island of Fiji.

Detrimental impacts of fossil fuels on climate and high demand of electricity in the southern Thailand which is from 5 to $6 \%$ yearly due to tourism industry and socio-economic development [15]. Krabi and Songkhla are located in the south Thailand. Krabi is a significant tourism area in Thailand and millions of tourists visit annually. Similarly, Songkhla hosts thousands of tourists each year due to its border with Malaysia [16,17]. Hence, wind energy is generally more favorable and often recommended for electricity generation.

Few studies on wind energy potential have been considered in the past using different models across Thailand, however, technical evaluation of wind energy potential using WAsP program along with different wind turbine models at selected sites is unknown. Therefore, this study aims to conduct wind energy potential of selected sites using near surface wind data obtained from Weather Observing Stations. The diurnal, monthly and frequency distribution of wind speed and direction are studied. WAsP program is used for energy yield calculations and wind resource maps using three different wind turbine models available in literature.

\section{Methodology}

\subsection{Overview of the Method}

The proposed methodology with a schematic diagram for the selected sites is presented in Figure 1. The first step involves the analysis of wind data acquired from Weather Observing Station. This data is further processed through WAsP Climate Analyst tool to generate wind statistics. This study utilizes 10-minutes average interval of wind data from a period of 3 to 4 years recorded at height of $10 \mathrm{~m}$ above ground level (AGL). The description of measurement sites and their geographical coordinates can be seen in Table 1. 


\section{Table 1}

Geographical coordinates and measurement duration of Krabi and Songkhla sites

\begin{tabular}{llllll}
\hline Station name & Latitude $\left({ }^{\circ}\right)$ & Longitude $\left({ }^{\circ}\right)$ & Height $(\mathrm{m})$ & $\begin{array}{l}\text { Measurement } \\
\text { duration }\end{array}$ & $\begin{array}{l}\text { Accepted } \\
\text { recording }(\%)\end{array}$ \\
\hline Krabi & 8.103 & 98.975 & 10 & $2017-2020$ & $93.87 \%$ \\
Songkhla & 7.18 & 100.60 & 10 & $2017-2019$ & $98.94 \%$ \\
\hline
\end{tabular}

The second step includes the coordinates and topographical information of the selected sites which are used as an input for WAsP Map Editor to generate elevation and roughness maps. The third step encompasses power curves of selected wind turbine models and site's wind characteristics in WAsP program to estimate energy yield calculations and resource maps of selected sites.

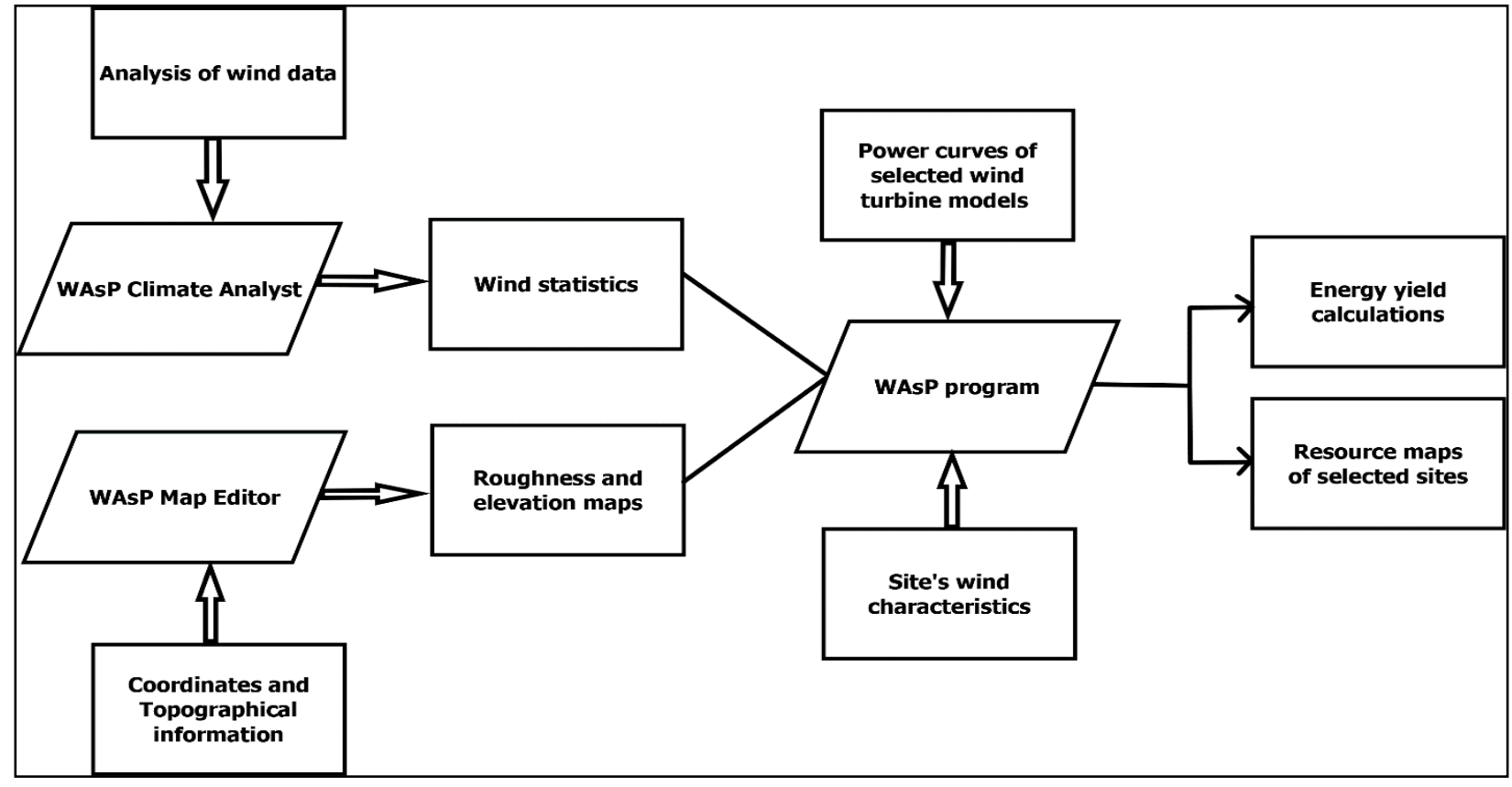

Fig. 1. Schematic diagram of methodology [4]

\subsection{Simulation Model}

WAsP is a computer-based linear simulation model established by Denmark Technical University (DTU) at Danish Riso National Laboratory. The WAsP model is computed for wind energy potential, site suitability analysis and calculations of energy yield for wind farms. It is used for vertical and horizontal extrapolation of wind data and shows errors less than $10 \%[4,18,19]$. The basic input information that are required for the WAsP program are the terrain height, surface roughness and obstacle effects. The WAsP program can perform all the necessary energy production calculations for a single turbine site or for a wind park along with the wake losses, layout, capacity factor and various other factors [4]. The WAsP model mainly belongs to the family of the Jackson-Hunt theory [20]. Inside WAsP Module there are two important tools i.e., WAsP Climate Analyst and WAsP Map Editor which are explained below.

This study uses the observed wind climatology as a data recording tool for WAsP Climate Analyst to estimate the wind conditions for the selected sites in terms of wind roses and Weibull distribution function. Furthermore, the wind rose is grouped into 12 sectors which signifies the relative frequency of wind direction. The Weibull distribution function is a two-parameter function which defines the 
wind speed histogram. WAsP utilizes this function for evaluation of wind characteristics in each direction by sector wise which can be expressed in mathematical form as [21]:

$f(v)=\frac{k}{A} *\left(\frac{v}{A}\right)^{k-1} * e^{-\left(\frac{v}{A}\right)^{k}}, k>0, v>0, A>1$

In Eq. (1), $f(v)$ denotes the Weibull distribution function, $v$ means the observed wind speed, $A$ and $k$ signify the scale and shape parameter of the Weibull distribution function, respectively.

WAsP Map Editor is a tool found inside WAsP module which is used to generate elevation and surface roughness maps for the selected sites. The important information of topography and surface roughness have been entered to the servers of Global Wind Atlas (GWA) Map Warehouse-Elevation and Global Wind Atlas (GWA) Map Warehouse-Roughness to complete the elevation and surface roughness maps.

\section{Results and Discussion}

This section describes the diurnal and monthly wind speed pattern. Besides, a comparative and comprehensive study of wind characteristics of the selected sites has been discussed.

\subsection{Diurnal Wind Speed}

Figure 2 displays average of wind speed of each hour recorded at $10 \mathrm{~m}$ height to show the wind speed diurnal pattern of Krabi and Songkhla sites. It has been observed that both sites examine maximum average wind speed from 2 a.m. to 8 a.m. with minimum average wind speed between 12 p.m. and 10 p.m.

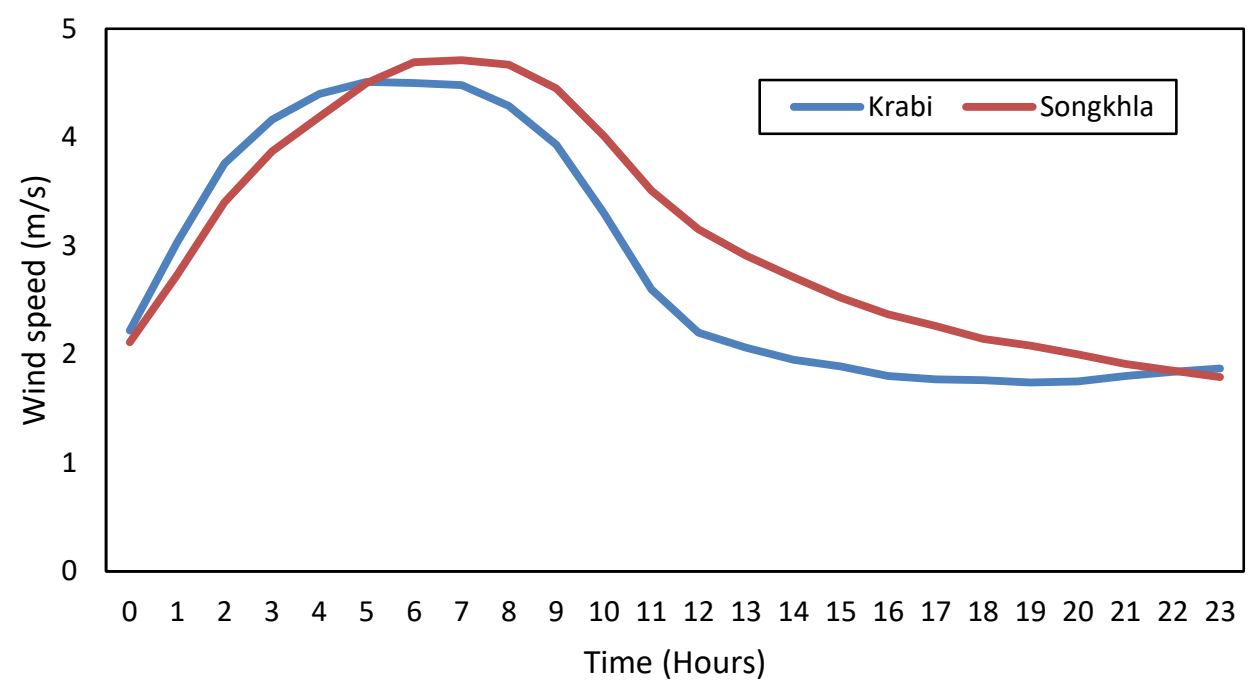

Fig. 2. Diurnal average wind speed for Krabi and Songkhla

\subsection{Monthly Wind Speed}

Figure 3 shows higher wind speed for Krabi site recorded at height of $10 \mathrm{~m} \mathrm{AGL}$ which has been observed between October and February with the maximum average wind speed value $4.39 \mathrm{~m} / \mathrm{s}$ in December. Similarly, the higher average wind speed for Songkhla site is experienced in January, February and August with the maximum average wind speed value $3.91 \mathrm{~m} / \mathrm{s}$ in February. The lowest 
average wind speed value of $2.02 \mathrm{~m} / \mathrm{s}$ have been observed in June for Krabi site and $2.56 \mathrm{~m} / \mathrm{s}$ in October for Songkhla site.

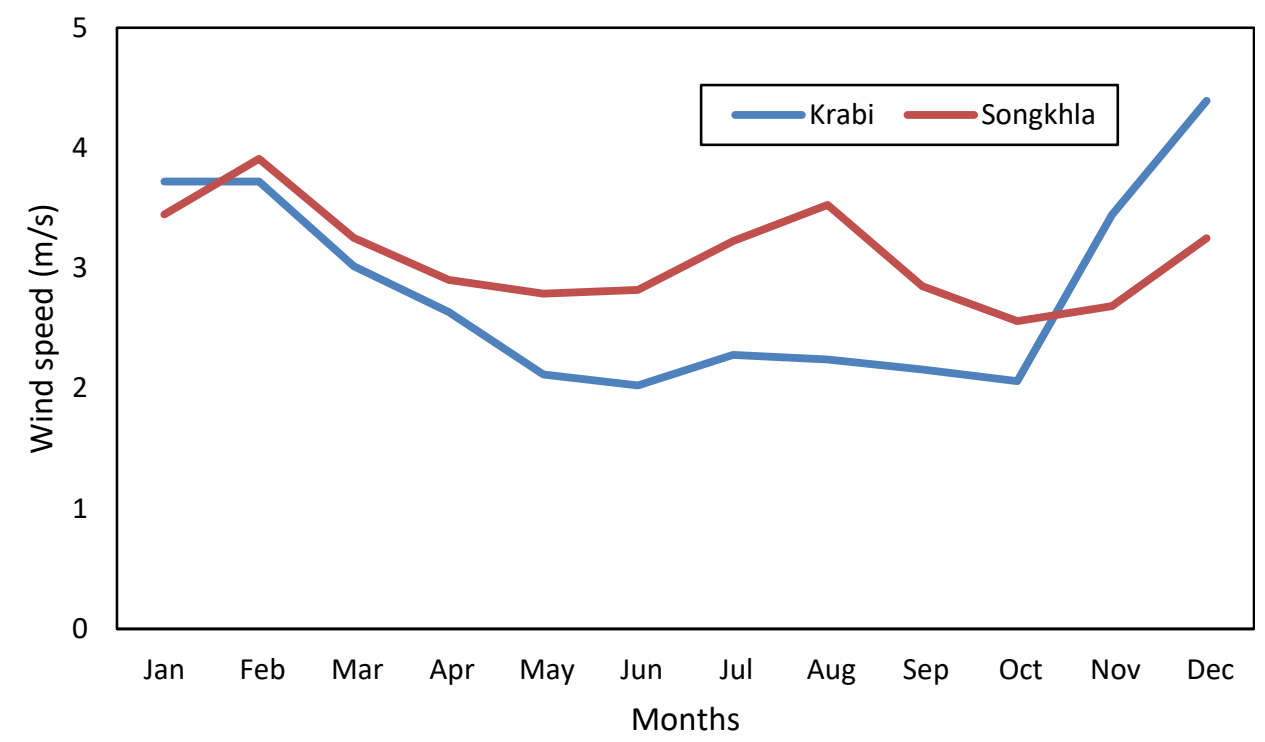

Fig. 3. Monthly average wind speed for Krabi and Songkhla

\subsubsection{Frequency distribution of wind speed and wind direction}

It is important to consider the frequency distribution of wind speed and wind direction during resource assessment as it gives site specific information.

Figure 4 shows the prevailing wind direction for Krabi which is north-east with a wind speed (3.73 $\mathrm{m} / \mathrm{s}$ ) frequency distribution $22.1 \%$. The values of scale parameter $A$ and shape parameter $\mathrm{k}$ are 3.1 $\mathrm{m} / \mathrm{s}$ and 1.39 , respectively.

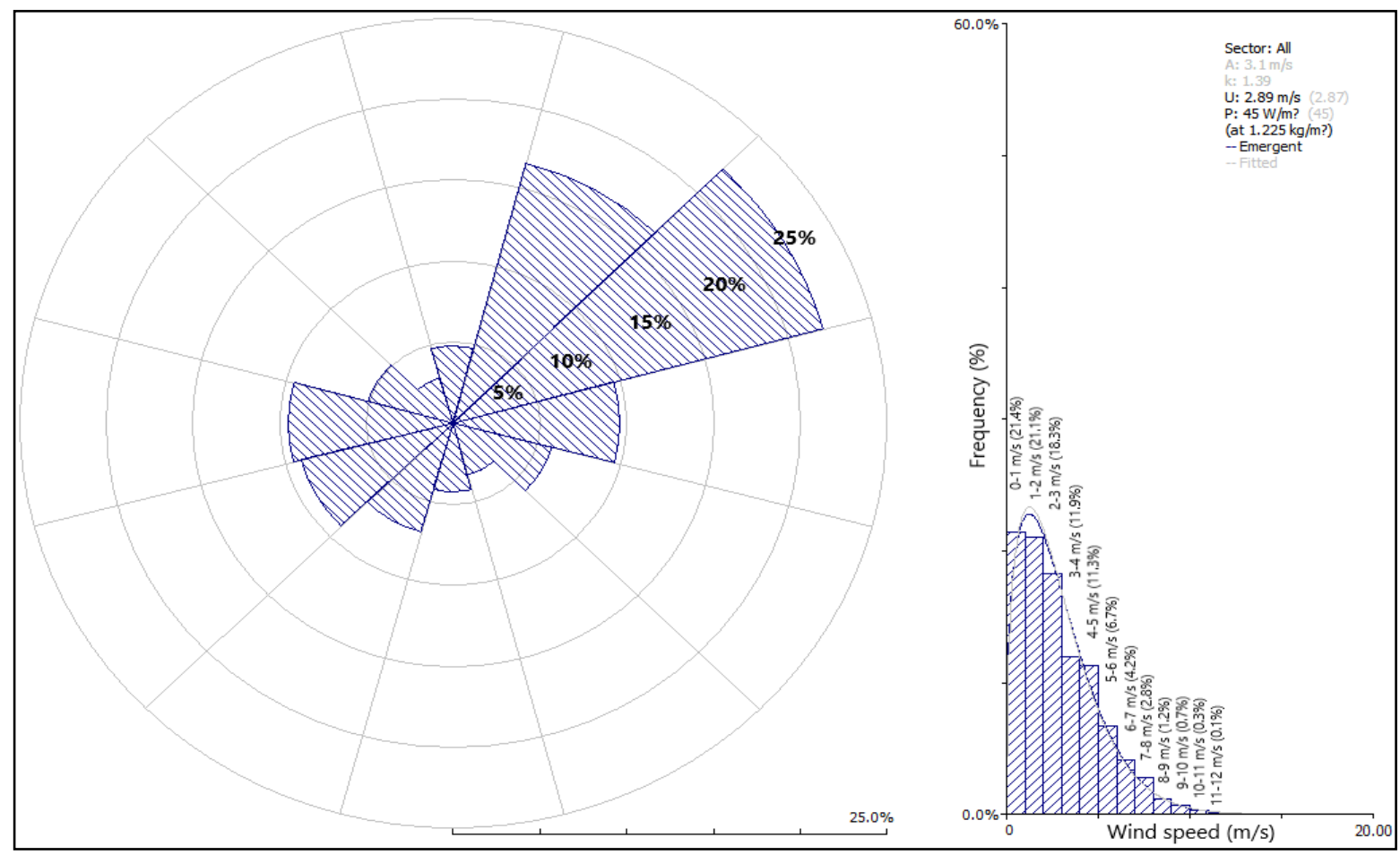

Fig. 4. Wind rose diagram and histogram of frequency distribution of wind speed for Krabi 
Figure 5 presents the prevailing wind direction for Songkhla which is south-east with a wind speed $(3.41 \mathrm{~m} / \mathrm{s})$ frequency distribution $31.3 \%$. The values of scale parameter $A$ and shape parameter $\mathrm{k}$ are $3.5 \mathrm{~m} / \mathrm{s}$ and 1.60 , respectively.

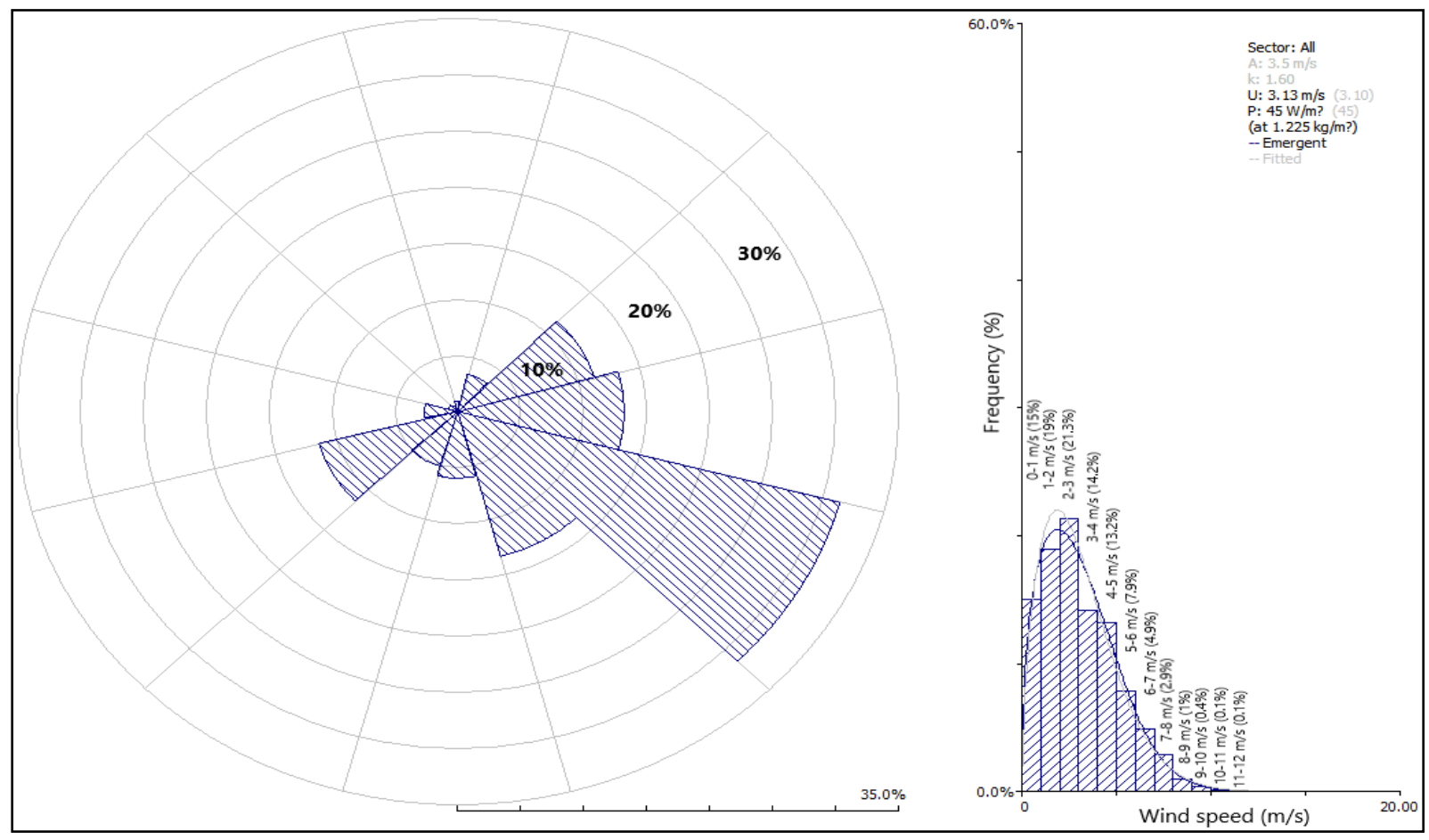

Fig. 5. Wind rose diagram and histogram of frequency distribution of wind speed for Songkhla

\subsubsection{Evaluation of wind characteristics}

WAsP program is utilized for evaluation wind energy potential and wind characteristics at Krabi and Songkhla sites by using three available wind turbine models in the literature. Technical description and specification of the wind turbine models are given in Table 2 .

\section{Table 2}

Specification of three wind turbines

\begin{tabular}{|c|c|c|c|c|c|c|c|}
\hline Wind turbine model & $\begin{array}{l}\text { Rated } \\
\text { output } \\
(\mathrm{kW})\end{array}$ & $\begin{array}{l}\text { Rotor } \\
\text { diameter } \\
(\mathrm{m})\end{array}$ & $\begin{array}{l}\text { Cut in } \\
\text { speed } \\
(\mathrm{m} / \mathrm{s})\end{array}$ & $\begin{array}{l}\text { Cut out } \\
\text { speed } \\
(\mathrm{m} / \mathrm{s})\end{array}$ & $\begin{array}{l}\text { Hub } \\
\text { height } \\
\text { (m) }\end{array}$ & $\begin{array}{l}\text { Swept } \\
\text { area } \\
\left(\mathrm{m}^{2}\right)\end{array}$ & $\begin{array}{l}\text { Rated } \\
\text { speed } \\
(\mathrm{m} / \mathrm{s})\end{array}$ \\
\hline Vergnet GEV MP-C 275 kW & 275 & 32 & 3.5 & 25 & 55 & 804 & 12 \\
\hline Bonus Mk III 300 kW & 300 & 33.4 & 3 & 25 & 30 & 876 & 13 \\
\hline Enercon E-40/5.40 $500 \mathrm{~kW}$ & 500 & 40.3 & 2.5 & 25 & 42 & 1,275 & 12 \\
\hline
\end{tabular}

The resource maps of Krabi and Songkhla using WAsP program are displayed in Figure 6 to Figure 11. The AEP estimated for Krabi using $275 \mathrm{~kW}$ wind turbine ranges from 35.162 to $964.939 \mathrm{MWh}$, with $300 \mathrm{~kW}$ wind turbine ranges from 0.006 to $1023 \mathrm{MWh}$ and with $500 \mathrm{~kW}$ wind turbine ranges from 0.038 to $1748 \mathrm{MWh}$. Similarly, the estimated AEP for Songkhla using $275 \mathrm{~kW}$ wind turbine ranges from 82.620 to $855.898 \mathrm{MWh}$, with $300 \mathrm{~kW}$ wind turbine ranges from 55.879 to $956.283 \mathrm{MWh}$ and with $500 \mathrm{~kW}$ wind turbine ranges from 0.125 to $1540 \mathrm{MWh}$. 


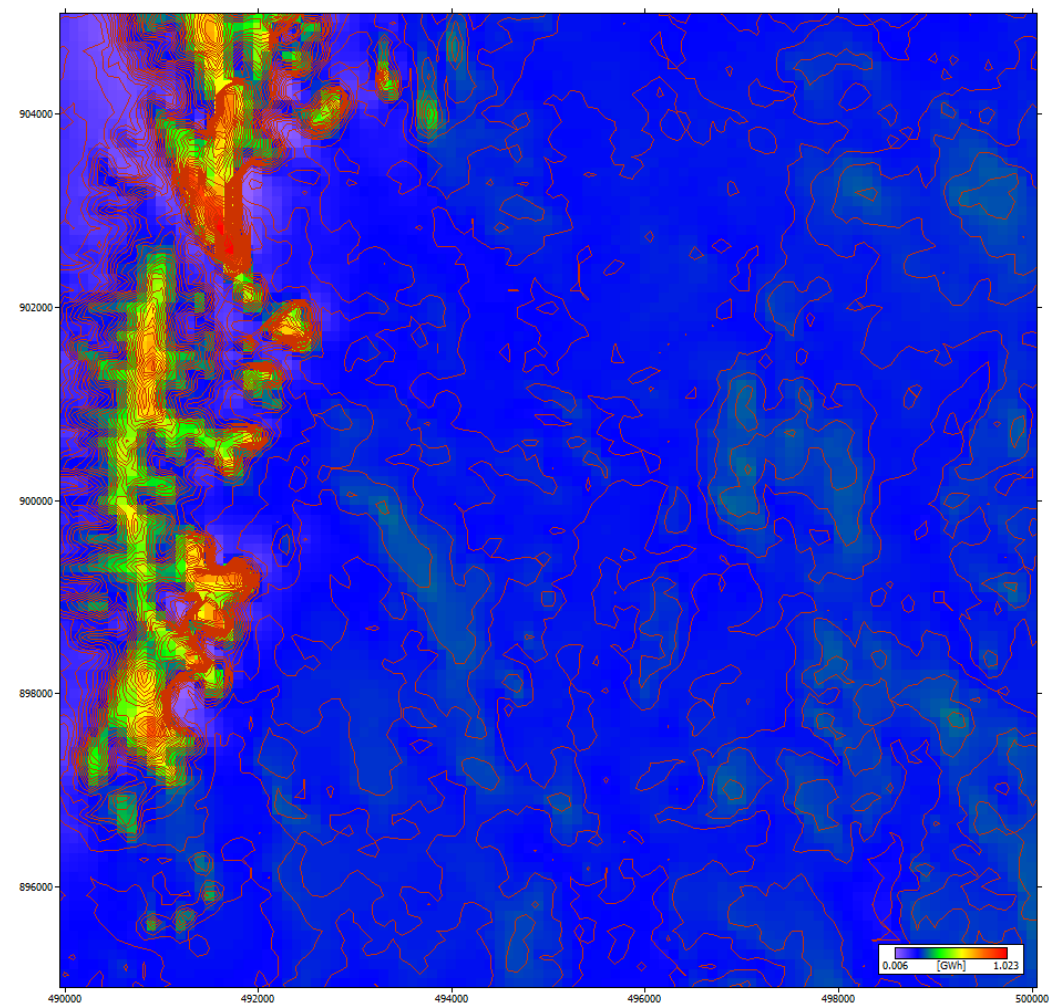

Fig. 6. Mean annual energy production of Krabi at $30 \mathrm{~m}$ hub height

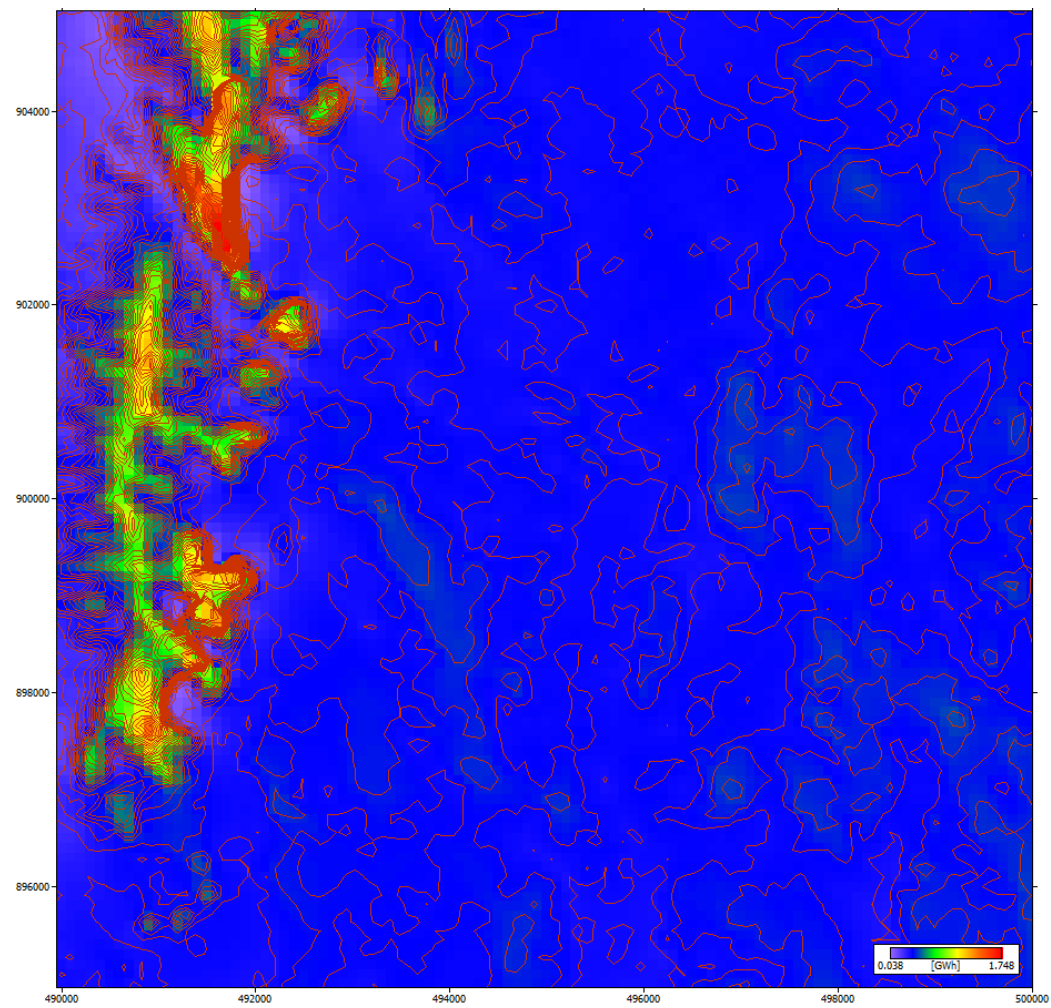

Fig. 7. Mean annual energy production of Krabi at $42 \mathrm{~m}$ hub height 


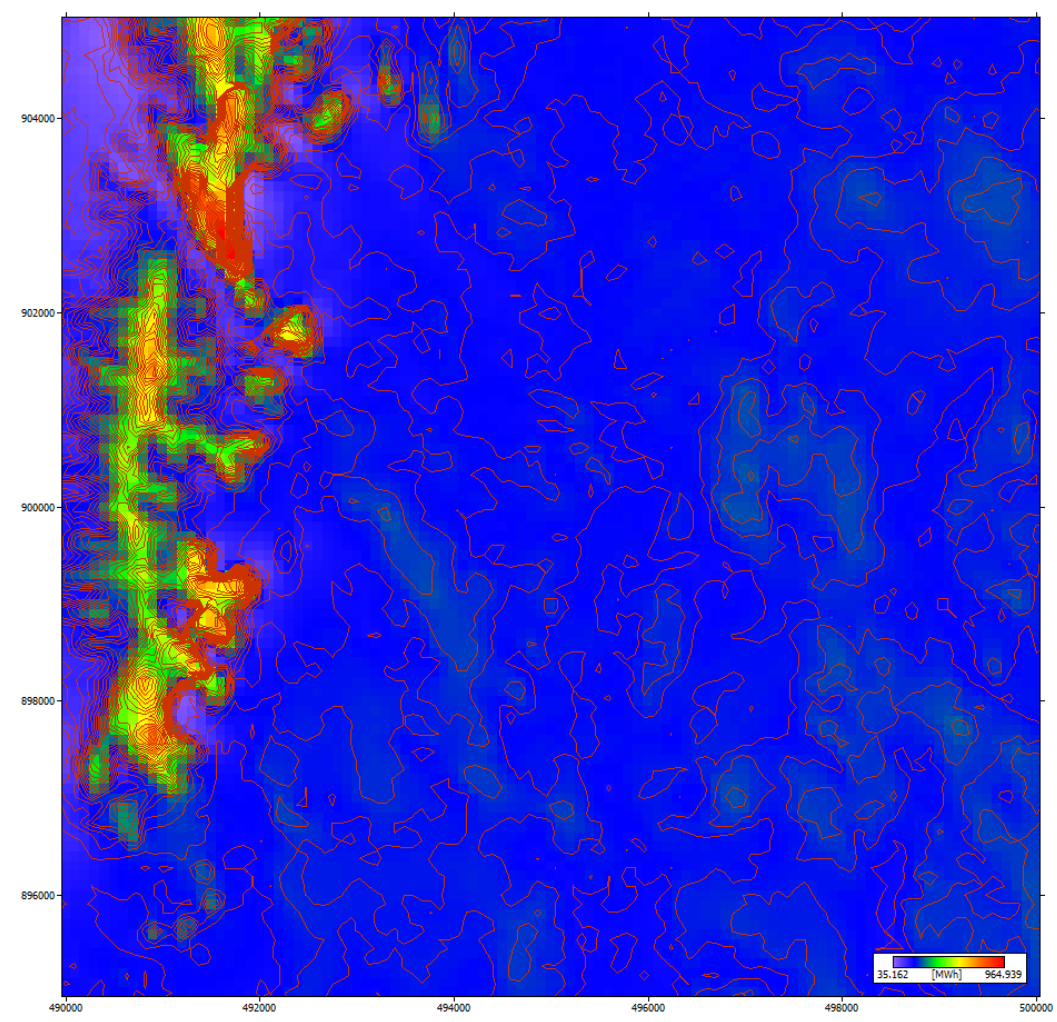

Fig. 8. Mean annual energy production of Krabi at $55 \mathrm{~m}$ hub height

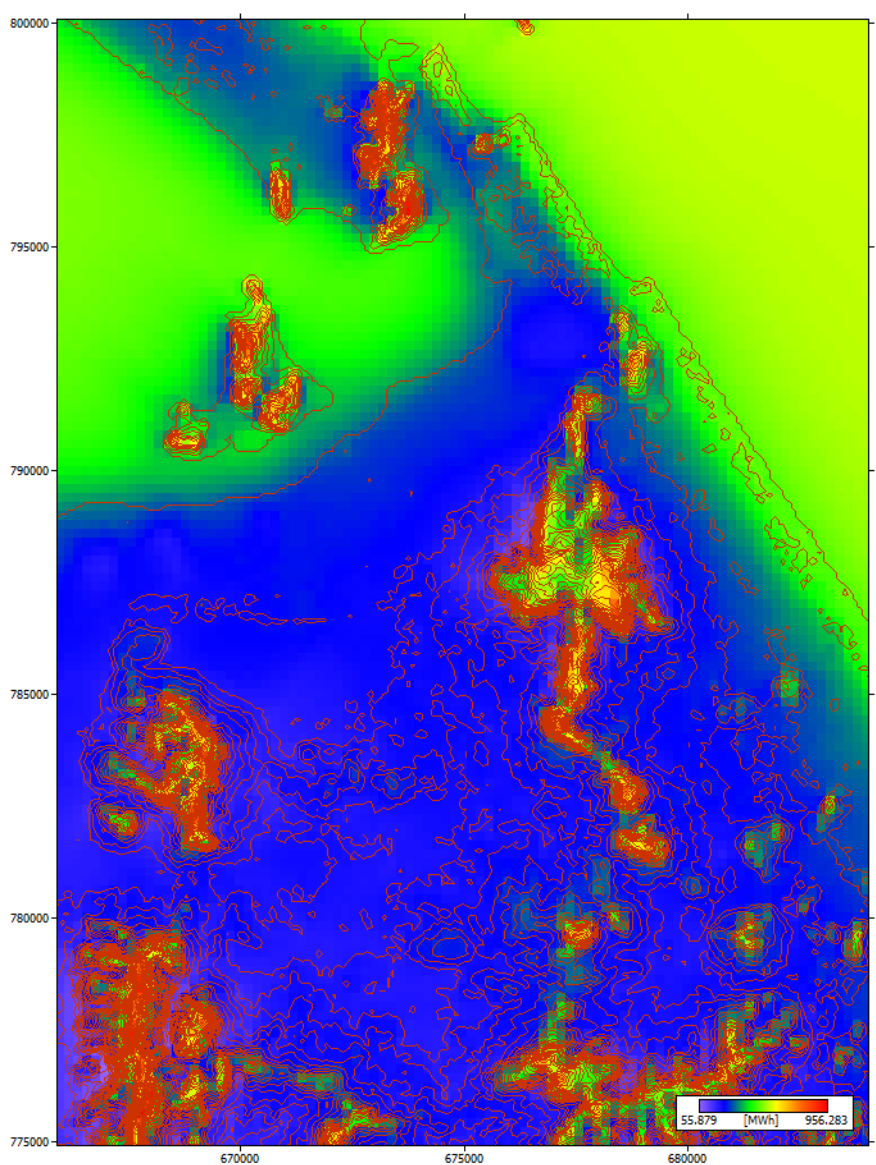

Fig. 9. Mean annual energy production of Songkhla at $30 \mathrm{~m}$ hub height 


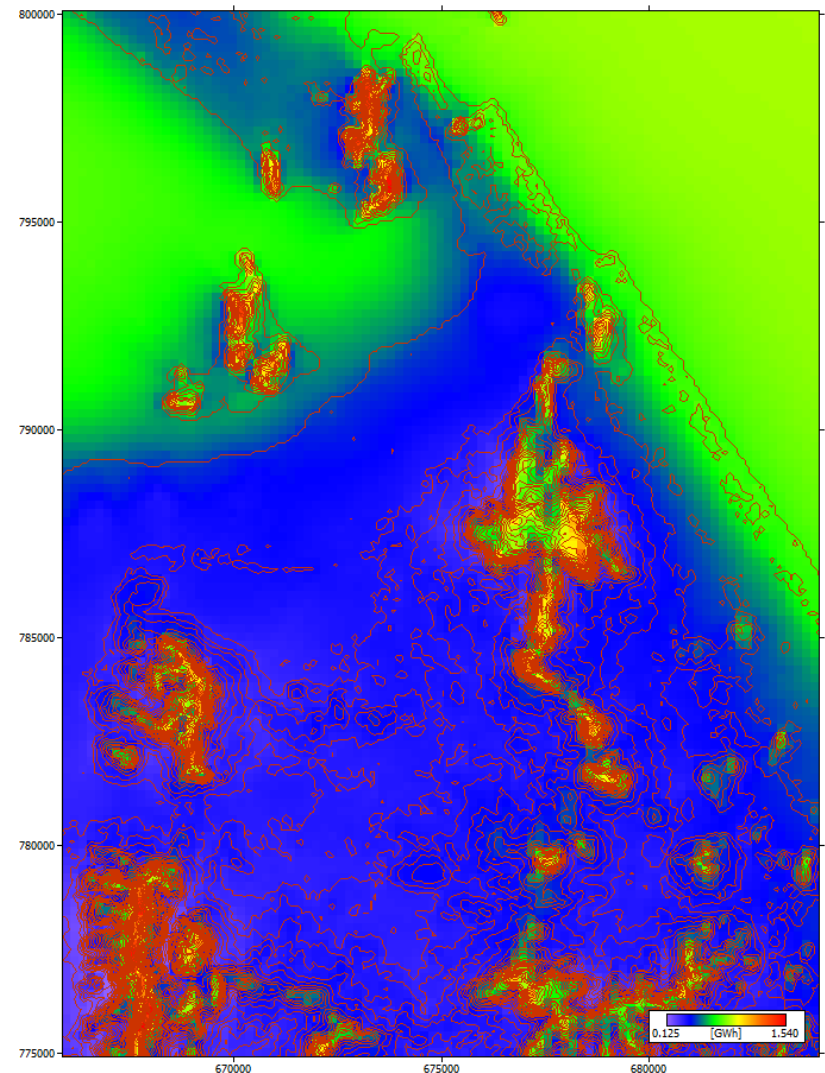

Fig. 10. Mean annual energy production of Songkhla at $42 \mathrm{~m}$ hub height

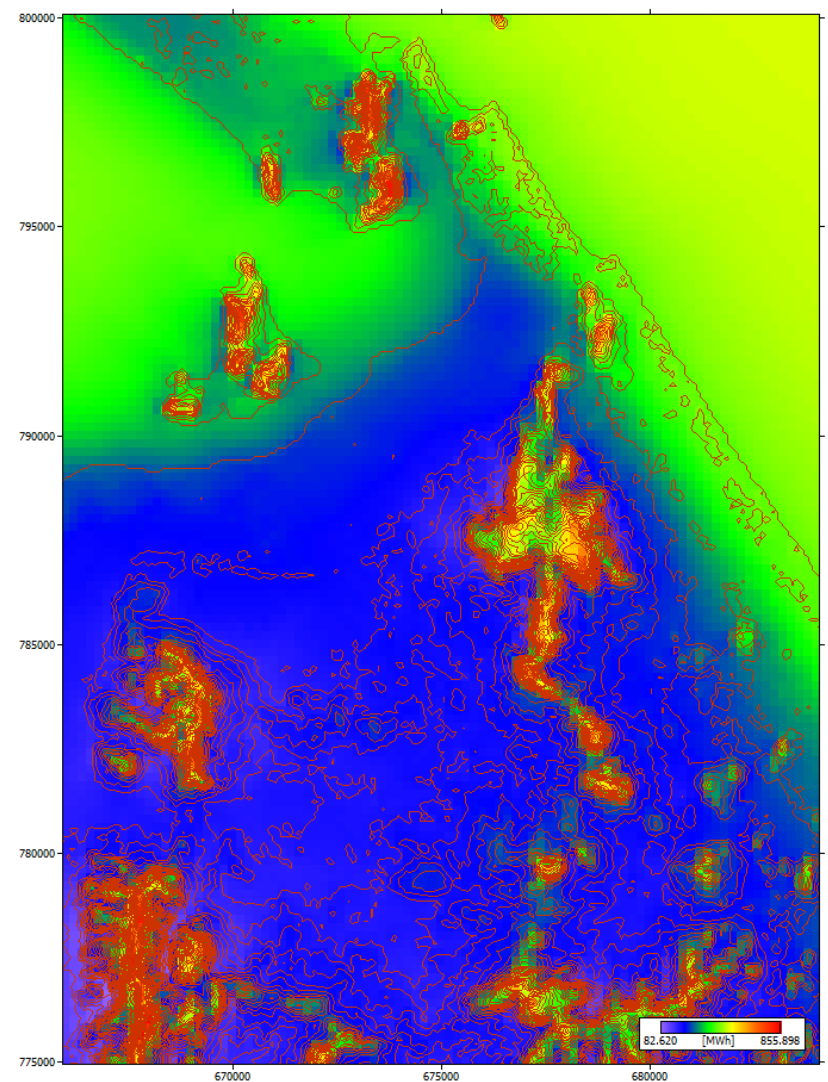

Fig. 11. Mean annual energy production of Songkhla at $55 \mathrm{~m}$ hub height 
The statistical analysis of Krabi and Songkhla sites in terms of total gross AEP, total net AEP, proportional wake losses, annual mean wind speed, annual power density and total capacity factor have been evaluated in this study.

The total gross AEP estimated for Krabi and Songkhla using wind turbine with rated capacity of $275 \mathrm{~kW}$ at $55 \mathrm{~m}$ hub height are $7172.545 \mathrm{MWh}$ and $7119.366 \mathrm{MWh}$, respectively. The mean speed and power density values are $6.85 \mathrm{~m} / \mathrm{s}$ and $501 \mathrm{~W} / \mathrm{m}^{2}$ for Krabi and $6.75 \mathrm{~m} / \mathrm{s}$ and $374 \mathrm{~W} / \mathrm{m}^{2}$ for Songkhla, respectively. The total capacity factor calculated for Songkhla and Krabi is $29.8 \%$ and $29.5 \%$, respectively. Further details for both sites are given in Table 3.

\section{Table 3}

Summary for annual statistics using Vergnet GEV MP-C $275 \mathrm{~kW}$ at $55 \mathrm{~m}$ height

\begin{tabular}{|c|c|c|c|c|c|c|c|c|}
\hline \multirow[t]{2}{*}{ Variable } & \multicolumn{2}{|l|}{ Total } & \multicolumn{2}{|l|}{ Mean } & \multicolumn{2}{|l|}{ Min } & \multicolumn{2}{|l|}{ Max } \\
\hline & Krabi & Songkhla & Krabi & Songkhla & Krabi & Songkhla & Krabi & Songkhla \\
\hline Total gross & 7172.545 & 7119.366 & 717.254 & 711.937 & 496.618 & 574.905 & 955.504 & 843.985 \\
\hline \multicolumn{9}{|l|}{ AEP [MWh] } \\
\hline $\begin{array}{l}\text { Total net AEP } \\
\text { [MWh] }\end{array}$ & 7163.782 & 7116.63 & 716.378 & 711.663 & 495.374 & 574.664 & 955.014 & 843.662 \\
\hline $\begin{array}{l}\text { Proportional } \\
\text { wake loss [\%] }\end{array}$ & 0.12 & 0.04 & - & - & 0.05 & 0.03 & 0.25 & 0.05 \\
\hline $\begin{array}{l}\text { Capacity } \\
\text { factor [\%] }\end{array}$ & 29.8 & 29.5 & - & - & 20.5 & 23.8 & 39.6 & 35 \\
\hline $\begin{array}{l}\text { Average speed } \\
{[\mathrm{m} / \mathrm{s}]}\end{array}$ & - & - & 6.85 & 6.75 & 5.59 & 6.15 & 8.48 & 7.38 \\
\hline $\begin{array}{l}\text { Wind power } \\
\text { density } \\
{\left[\mathrm{W} / \mathrm{m}^{2}\right]}\end{array}$ & - & - & 501 & 374 & 260 & 278 & 972 & 477 \\
\hline
\end{tabular}

The total gross AEP estimated for Krabi and Songkhla using wind turbine with rated capacity of $300 \mathrm{~kW}$ at $30 \mathrm{~m}$ hub height are $7768 \mathrm{MWh}$ and $7775.964 \mathrm{MWh}$, respectively. The mean speed and power density values are $6.87 \mathrm{~m} / \mathrm{s}$ and $590 \mathrm{~W} / \mathrm{m}^{2}$ for Krabi and $6.55 \mathrm{~m} / \mathrm{s}$ and $378 \mathrm{~W} / \mathrm{m}^{2}$ for Songkhla, respectively. The total capacity factor calculated for Songkhla and Krabi is $29.1 \%$. Further details for both sites are given in Table 4.

\section{Table 4}

Summary for annual statistics using Bonus Mk III $300 \mathrm{~kW}$ at $30 \mathrm{~m}$ height

\begin{tabular}{|c|c|c|c|c|c|c|c|c|}
\hline \multirow[t]{2}{*}{ Variable } & \multicolumn{2}{|l|}{ Total } & \multicolumn{2}{|l|}{ Mean } & \multicolumn{2}{|l|}{ Min } & \multicolumn{2}{|l|}{ Max } \\
\hline & Krabi & Songkhla & Krabi & Songkhla & Krabi & Songkhla & Krabi & Songkhla \\
\hline Total gross & 7768 & 7775.964 & 777 & 777.596 & 539 & 644.544 & 1014 & 894.461 \\
\hline AEP [MWh] & & & & & & & & \\
\hline $\begin{array}{l}\text { Total net AEP } \\
\text { [MWh] }\end{array}$ & 7762 & 7775.245 & 776 & 777.524 & 538 & 644.525 & 1013 & 894.316 \\
\hline $\begin{array}{l}\text { Proportional } \\
\text { wake loss [\%] }\end{array}$ & 0.07 & 0.01 & - & - & 0.02 & 0 & 0.16 & 0.02 \\
\hline $\begin{array}{l}\text { Capacity } \\
\text { factor [\%] }\end{array}$ & 29.1 & 29.1 & - & - & 20.1 & 24.1 & 37.9 & 33.4 \\
\hline $\begin{array}{l}\text { Average speed } \\
{[\mathrm{m} / \mathrm{s}]}\end{array}$ & - & - & 6.87 & 6.55 & 5.28 & 5.92 & 9.19 & 7.13 \\
\hline $\begin{array}{l}\text { Wind power } \\
\text { density } \\
{\left[\mathrm{W} / \mathrm{m}^{2}\right]}\end{array}$ & - & - & 590 & 378 & 260 & 280 & 1400 & 488 \\
\hline
\end{tabular}


The total gross AEP estimated for Krabi and Songkhla using wind turbine with rated capacity of $500 \mathrm{~kW}$ at $42 \mathrm{~m}$ hub height are $12738 \mathrm{MWh}$ and $12391 \mathrm{MWh}$, respectively. The mean speed and power density values are $6.85 \mathrm{~m} / \mathrm{s}$ and $533 \mathrm{~W} / \mathrm{m}^{2}$ for Krabi and $6.66 \mathrm{~m} / \mathrm{s}$ and $372 \mathrm{~W} / \mathrm{m}^{2}$ for Songkhla, respectively. The total capacity factor calculated for Songkhla and Krabi is $29.1 \%$ and $28.3 \%$, respectively. Further details for both sites are given in Table 5.

\section{Table 5}

Summary for annual statistics using Enercon E-40/5.40 $500 \mathrm{~kW}$ at $42 \mathrm{~m}$ height

\begin{tabular}{lllllllll}
\hline Variable & $\begin{array}{l}\text { Total } \\
\text { Krabi }\end{array}$ & Songkhla & $\begin{array}{l}\text { Mean } \\
\text { Krabi }\end{array}$ & Songkhla & $\begin{array}{l}\text { Krabi } \\
\text { Krabi }\end{array}$ & Songkhla & $\begin{array}{l}\text { Kax } \\
\text { Krabi }\end{array}$ & Songkhla \\
\hline $\begin{array}{l}\text { Total gross } \\
\text { AEP [MWh] }\end{array}$ & 12738 & 12391 & 1274 & 1239 & 863 & 998 & 1732 & 1468 \\
$\begin{array}{l}\text { Total net AEP } \\
\text { [MWh] }\end{array}$ & 12731 & 12390 & 1273 & 12390 & 861 & 998 & 1732 & 1468 \\
$\begin{array}{l}\text { Proportional } \\
\text { wake loss [\%] }\end{array}$ & 0.06 & 0.01 & - & - & 0.01 & 0 & 0.13 & 0.02 \\
$\begin{array}{l}\text { Capacity } \\
\text { factor [\%] }\end{array}$ & 29.1 & 28.3 & - & - & 19.7 & 22.8 & 39.5 & 33.5 \\
$\begin{array}{l}\text { Average speed } \\
\text { [m/s] }\end{array}$ & - & - & 6.85 & 6.66 & 5.44 & 6.03 & 8.76 & 7.29 \\
$\begin{array}{l}\text { Wind power } \\
\text { density } \\
{\left[\mathrm{W} / \mathrm{m}^{2} \text { ] }\right.}\end{array}$ & - & - & 533 & 373 & 258 & 276 & 1131 & 475 \\
\hline
\end{tabular}

The results reveal that Enercon E-40/5.40 $500 \mathrm{~kW}$ wind turbine produces the highest total gross AEP and net AEP for Krabi and Songkhla sites. The annual capacity factor slightly varies for the selected wind turbines as it depends on turbine model and site. The Vergnet GEV MP-C $275 \mathrm{~kW}$ shows slightly higher capacity factor for both sites.

\section{Conclusion}

This study has used the recent meteorological wind data for Krabi and Songkhla sites to study the technical potential of wind energy by using three wind turbine models available in literature. The main points of wind resource analysis of both sites are:

i. Both Krabi and Songkhla sites observe maximum diurnal average wind speed from 2 a.m. to 8 a.m. at height of $10 \mathrm{~m} \mathrm{AGL}$.

ii. Krabi site shows maximum average wind speed of $4.39 \mathrm{~m} / \mathrm{s}$ in December while Songkhla site indicates the maximum average wind speed of $3.91 \mathrm{~m} / \mathrm{s}$ in February at height of $10 \mathrm{~m} \mathrm{AGL}$.

iii. The prevailing wind direction in Krabi is north-east. The Weibull scale parameter $A$ and shape parameter $k$ values are $3.1 \mathrm{~m} / \mathrm{s}$ and 1.39 , respectively.

iv. The prevailing wind direction in Songkhla is south-east with a wind speed. The Weibull scale parameter $A$ and shape parameter $k$ values are $3.5 \mathrm{~m} / \mathrm{s}$ and 1.60 , respectively.

v. The total net AEP estimated for Krabi using $275 \mathrm{~kW}, 300 \mathrm{~kW}$ and $500 \mathrm{~kW}$ wind turbine models is $7163.782 \mathrm{MWh}, 7762 \mathrm{MWh}$ and $12731 \mathrm{MWh}$, respectively.

vi. The total net AEP estimated for Songkhla using $275 \mathrm{~kW}, 300 \mathrm{~kW}$ and $500 \mathrm{~kW}$ wind turbine models is $7116.63 \mathrm{MWh}, 7775.245 \mathrm{MWh}$ and $12390 \mathrm{MWh}$, respectively.

vii. The value of capacity factor for Songkhla and Krabi is $29.1 \%$ and $28.3 \%$, respectively.

viii. WAsP analysis shows that Enercon E-40/5.40 $500 \mathrm{~kW}$ generates the highest total gross AEP and total net AEP for Krabi and Songkhla sites. 
ix. Regarding capacity factor, the Vergnet GEV MP-C $275 \mathrm{~kW}$ turbine model shows slightly higher capacity factor in case of both sites.

The results of the study at various hub heights confirm that both sites can be used to generate wind energy electricity in future. However, further investigation regarding cost analysis for each site would be required.

\section{Acknowledgment}

This work was supported by Prince of Songkla University Hat Yai, Songkhla 90112, Thailand, by the grant of an Interdisciplinary Graduate School (IGS), and partially supported by the Faculty of Engineering, Prince of Songkla University and the Graduate School, Prince of Songkla University with Graduate School thesis research funding. The authors acknowledge the help of the Thai Meteorological Department (TMD) by providing the wind data.

\section{References}

[1] Pishgar-Komleh, S. H., and A. Akram. "Evaluation of wind energy potential for different turbine models based on the wind speed data of Zabol region, Iran." Sustainable Energy Technologies and Assessments 22 (2017): 34-40. https://doi.org/10.1016/i.seta.2017.05.007

[2] Mohamadi, Hossein, Alireza Saeedi, Zahra Firoozi, Saeid Sepasi Zangabadi, and Shahla Veisi. "Assessment of wind energy potential and economic evaluation of four wind turbine models for the east of Iran." Heliyon 7, no. 6 (2021): e07234. https://doi.org/10.1016/i.heliyon.2021.e07234

[3] Akpinar, E. Kavak, and S. Akpinar. "A statistical analysis of wind speed data used in installation of wind energy conversion systems." Energy Conversion and Management 46, no. 4 (2005): 515-532. https://doi.org/10.1016/i.enconman.2004.05.002

[4] Kamdar, Ismail, Shahid Ali, Juntakan Taweekun, and Hafiz Muhammad Ali. "Wind Farm Site Selection Using WAsP Tool for Application in the Tropical Region." Sustainability 13, no. 24 (2021): 13718. https://doi.org/10.3390/su132413718

[5] Zhou, Y., W. X. Wu, and G. X. Liu. "Assessment of onshore wind energy resource and wind-generated electricity potential in Jiangsu, China." Energy Procedia 5 (2011): 418-422. https://doi.org/10.1016/i.egypro.2011.03.072

[6] Yaniktepe, B., T. Koroglu, and M. M. Savrun. "Investigation of wind characteristics and wind energy potential in Osmaniye, Turkey." Renewable and Sustainable Energy Reviews 21 (2013): $703-711$. https://doi.org/10.1016/i.rser.2013.01.005

[7] Adaramola, Muyiwa S., Martin Agelin-Chaab, and Samuel S. Paul. "Assessment of wind power generation along the coast of Ghana." Energy Conversion and Management $77 \quad$ (2014): 61-69. https://doi.org/10.1016/j.enconman.2013.09.005

[8] Solyali, Davut, Mustafa Altunç, Süleyman Tolun, and Zafer Aslan. "Wind resource assessment of Northern Cyprus." Renewable and Sustainable Energy Reviews 55 (2016): 180-187. https://doi.org/10.1016/i.rser.2015.10.123

[9] Wang, Jianzhou, Jianming Hu, and Kailiang Ma. "Wind speed probability distribution estimation and wind energy assessment." Renewable and Sustainable Energy Reviews $60 \quad$ (2016): 881-899. https://doi.org/10.1016/i.rser.2016.01.057

[10] Promsen, W., S. Janjai, and T. Tantalechon. "An analysis of wind energy potential of Kampot Province, Southern Cambodia." Energy Procedia 52 (2014): 633-641. https://doi.org/10.1016/i.egypro.2014.07.119

[11] Nouri, Abdellatif, Mohamed Ait Babram, Elmostafa Elwarraki, and Mustapha Enzili. "Moroccan wind farm potential feasibility. Case study." Energy Conversion and Management 122 (2016): 39-51. https://doi.org/10.1016/j.enconman.2016.05.058

[12] Boudia, Sidi Mohammed, and Ouahiba Guerri. "Investigation of wind power potential at Oran, northwest of Algeria." Energy Conversion and Management $105 \quad$ (2015): https://doi.org/10.1016/j.enconman.2015.07.055

[13] Mohammadi, Kasra, Omid Alavi, Ali Mostafaeipour, Navid Goudarzi, and Mahdi Jalilvand. "Assessing different parameters estimation methods of Weibull distribution to compute wind power density." Energy Conversion and Management 108 (2016): 322-335. https://doi.org/10.1016/j.enconman.2015.11.015

[14] Sharma, Kaushik, and M. Rafiuddin Ahmed. "Wind energy resource assessment for the Fiji Islands: Kadavu Island and Suva peninsula." Renewable Energy 89 (2016): 168-180. https://doi.org/10.1016/j.renene.2015.12.014 
[15] EGAT. "Why does the South of Thailand need coal-fired power plants?" Electricity Generating Authority of Thailand. Accessed March 24, 2021. https://www.egat.co.th/en/news-announcement/egat-reasons-why/why-does-thesouth-of-thailand-need-coal-fired-power-plants

[16] Kamdar, Ismail, Shahid Ali, Adul Bennui, Kuaanan Techato, and Warangkana Jutidamrongphan. "Municipal solid waste landfill siting using an integrated GIS-AHP approach: A case study from Songkhla, Thailand." Resources, Conservation and Recycling 149 (2019): 220-235. https://doi.org/10.1016/i.resconrec.2019.05.027

[17] Kamdar, I., and J. Taweekun. "Assessment of wind energy potential of Hat Yai (Songkhla), Thailand." In IOP Conference Series: Materials Science and Engineering, vol. 1163, no. 1, p. 012001. IOP Publishing, 2021. https://doi.org/10.1088/1757-899X/1163/1/012001

[18] Liu, Junkai, Chloe Y. Gao, Jingzhen Ren, Zhiqiu Gao, Hanwei Liang, and Linlin Wang. "Wind resource potential assessment using a long term tower measurement approach: A case study of Beijing in China." Journal of Cleaner Production 174 (2018): 917-926. https://doi.org/10.1016/i.jclepro.2017.10.347

[19] Fang, Hsin-Fa. "Wind energy potential assessment for the offshore areas of Taiwan west coast and Penghu Archipelago." Renewable Energy 67 (2014): 237-241. https://doi.org/10.1016/i.renene.2013.11.047

[20] Jackson, P. S., and J. C. R. Hunt. "Turbulent wind flow over a low hill." Quarterly Journal of the Royal Meteorological Society 101, no. 430 (1975): 929-955. https://doi.org/10.1002/qj.49710143015

[21] Romanic, Djordje, Dan Parvu, Maryam Refan, and Horia Hangan. "Wind and tornado climatologies and wind resource modelling for a modern development situated in "Tornado Alley"." Renewable Energy 115 (2018): 97-112. https://doi.org/10.1016/i.renene.2017.08.026 